\title{
DETERMINANTS OF FINANCIAL MANAGEMENT BEHAVIOR OF MILLENNIAL GENERATION IN SURABAYA
}

\author{
Aditya Yanuar Ramadhan and Nadia Asandimitra* \\ Universitas Negeri Surabaya, Indonesia
}

\begin{abstract}
The habit of millennial generations in Surabaya in conducting online shopping activities can influence their financial management behavior. This study aims to investigate the factors that can affect financial management behavior with a sample of 184 millennial generations in Surabaya using multiple linear regressions. The findings demonstrated that financial attitude, financial knowledge, and secondary agents had a positive effect on financial management behavior. Whereas locus of control, childhood consumer experience, and primary agent did not affect on financial management behavior. Millennial generations in Surabaya have financial attitudes and knowledge, while also supported by adequate digital and internet literation.
\end{abstract}

Keywords: financial attitude, financial knowledge, financial management behavior, millennial generations, the socialization agent

*Corresponding author: adit.anu31@gmail.com

DOI: $10.24252 /$ minds.v6i2.9506 


\section{INTRODUCTION}

There are so many definitions of demography which can be found in the literature. Noble \& Schewe (2003) categorize the demography groups into fourgeneration; they are Baby boomer generation, $X$ generation, Millennials generation, and $\mathrm{Z}$ generation. Based on Badan Pusat Statistik (Statistics Indonesia), $50 \%$ of the population is on their productive age. They are considered as the millennials generation and predicted that in 2020 until 2030, the percentage will increase into $70 \%$ from the total amount of Indonesian people in their productive age (Ali \& Purwandi, 2017). Millennials are often considered as the generation who are creative, have interesting ideas, have productive character, but they are also consumptive. These characteristics occurred because of the digital culture and internet effect. The Association of Internet Service Provider of Indonesia (APJII) in 2018 stated that the internet has a significant role in Indonesian people's life. The millennials generation uses the internet in their needs. For example, transaction, transportation, food, walking out, also shop for their clothes and daily necessities (CNN Indonesia, 2018).

The good thing from the digital culture and the use of the internet is the millennial generation's movement becomes faster. Making a transaction by internet can remove many obstacles that may appear in the physical purchase. However, it might raise the adverse effect of consumptive behaviors. The new research conducted by Google and GfK (Gesellschaft für Konsumforschung) research institution explained that online shopping is a general activity in Indonesia, and more than percent of the consumer in big cities have visited ecommerce platforms. This type of trend is not only centered in the capital city, although the percentage of online shopping in Jakarta is pretty high which is $66 \%$, in Medan 68\%, and in Surabaya is higher in $71 \%$.

Based on a snap card survey, the people in 25-34 years old are the millennials generation in the first position with a percentage of 50\% (Sugianto, 2018). It also showed that millennials generation are so active in using the internet also becomes the most consumptive generation. This consumptive behavior will affect their financial management behavior very much. A person's financial management behavior can be known from how they are consuming, what kind of things they consume, and why they buy. Four indicators could explain financial management behavior, namely Consumption, Cash-flow management, Saving and Investment, and Credit management (Dew \& Xiao, 2011). Sound financial management behavior is leading to more responsible behavior. The appearance of financial management behavior is because of the enormous desire of a person to fulfill their life needs, which based on the income level they earned (Kholilah \& Iramani, 2013). This study's purpose is to investigate several factors 
affecting the financial management behavior of the millennial generation in Surabaya.

\section{THEORETICAL REVIEW}

Theory of Planned Behavior

Ajzen (1991) said that every person is doing something because of their intention and a purpose to be achieved, which becomes the basic theory of planned behavior and considered as the basic theory to do the predicted planned behavior. It helps to understand how to change another person's behavior. A person does a particular action because they have an intention also purpose. The intention of a person's behavior is determined by some factors which are Attitudes, interpreted explicitly as the positive or negative assessment of their attitude to be created as their behavior of how they exactly going to do; Subjective Norms, another person's thought about the support in doing something; and Perceived Behavioral Control, as the individual perception about the ease and difficulty in doing their activity. Ajzen (2005) gave another background factor of an individual in the Theory of Planned Behavior, which is consists of three elements, social, personal, and information.

\section{Social Learning Theory}

In 1996, the social learning theory was introduced by Julian Rotter. He explained the proposition is comprised of four main concepts, they are potential behavior, hopes, reinforcement value, and psychological situation. Social learning theory made the reinforcement concept where there is a belief of a person's study history might lead them into the hopes about the reinforcement and able to see the positive or negative rewards as a result towards their behavior or depend on the out of control effect (Rotter, 1966).

\section{Financial Management behavior}

Financial management is related to the acquisition, financing, and asset management. For a reason, the function of financial management decision can be divided into three main fields: investment, funding, and asset management decision (Van Horne \& Wachowicz, 2006) meanwhile based on Kholilah \& Iramani (2013), Financial management behavior is a person's capacity in managing their daily fund. Financial behavior tends to responsible finance behavior so that it can be managed well. Financial management behavior's first time appeared because of the massive desire of a person to fulfill their life needs which is appropriate to their income. Financial management behavior is measured by using the parameter which consists of the outlay control, debt 
accuracy, future financial plan, family and individual fund provision, and the safety of saving money (Novianti et al., 2016).

\section{Locus of Control}

Julian Rotter mentions locus of control in 1966 which is about how people see an event related to how they overcome it when it comes to them. It comes with two main points, internal and external locus of control (Robbins \& Timothy, 2008). A person who assumes that skill, effort, and ability are the aspects which can decide things they can obtain in life is called as internal locus of control and a person who assume that fate is based on the outside strength, for instance, luck, destiny, and also authority is considered as external locus of control (Kholilah \& Iramani, 2013). Locus of control be observed from some parameters which are derived from skill in problem-solving, the influence of environment towards themselves, power to change important decision in life, skill in practicing ideas in their mind, a belief to the future events, skill to face the life problems, and also control towards the recent events Ida \& Dwinta (2010).

Rotter (1966) explained that locus of control is the hope, attitude, or belief towards the relation of behavior and the consequence. The influence of locus of control towards the financial management behavior based on the theory of social learning which mentioned that if a concept in social learning theory which the reinforcement to the central position and have a belief that in their learning process, a person can directing to the hope and see the negative or positive reward into something which based on their attitude or outside effect. Kholilah \& Iramani (2013) explained that if a person tends to an excellent internal locus of control, better financial management behavior will follow because of better selfcontrol. Al Kholilah \& Iramani (2013) found that locus of control influences towards financial management behavior positively. For instance, when a person tends to the internal locus of control, so their financial management behavior will be better. Those finding is in contrast with Britt et al. (2011) and Thi et al. (2015). They stated that locus of control influences negatively to financial management behavior. The finding is also different from Novianti et al. (2016) that there is no influence between locus of control towards financial management behavior. Thus, the hypothesis is as follows, H1: There is an influence between locus of control towards financial management behavior to the millennial generation in Surabaya.

\section{Financial Attitude}

Attitude refers to how people feel in personal financial matters, which is measured by the response of questions or opinions (Marsh, 2006). Humaira \& Sagoro (2018) mentioned that attitude is a condition of mind, view, and a person's 
perspective in measuring the world he lives in so that the financial attitude defined as the condition of mind, opinion, and how people measure their financial status and implement it to their attitude. For the reason, financial attitude can be said that it also influences how individuals manage their financial (Herdjiono \& Damanik, 2016). Herdjiono \& Damanik (2016) also stated that to measure the financial attitude, a parameter is needed, which consists of reliable money, controller money, problem-solving money, responding money, saving money, the need for money and financial control.

Financial attitude is a tendency of a person's psychological side, which expressed in evaluating the practice of financial management that recommended by many kinds of levels in a deal or no deal (Amanah et al., 2016). The influence of financial attitude towards financial management behavior based on the theory of planning attitude. The postulate explained that people behave according to their intention and purpose that in doing the action, it is based on several things; one of them is the personal factor, which is the attitude. A person who assumes that their financial behavior is good will tend to face the financial behavior problem rarely because they have a wise manner in meeting the financial challenge. Amanah et al. (2016) mentioned that financial attitude gives a positive influence towards financial management behavior because by having proper financial management is more critical to manage the stability and development of family finance to have financial satisfaction. It is in contrast with the finding mentioned by Falahati et al. (2012), where commercial attitude has a negative influence on financial management behavior. The result is also dissimilar to Rizkiawati \& Asandimitra (2018) that showed the financial attitude does not influence financial management behavior. The reason is that every respondent has a different point of view in facing the financial problem (Rizkiawati \& Asandimitra, 2018). Thus, the hypothesis is as follows, H2: There is an influence between financial attitude towards financial management behavior to the millennial generation in Surabaya.

\section{Financial Knowledge}

Financial knowledge is a way to take the financial decision where a person needs to improve their money-related skills and tools (Kholilah \& Iramani, 2013). Financial knowledge is not only making people wise in using funds but also give economic benefits (Herdjiono \& Damanik, 2016). Novianti et al. (2016) used a parameter to measure financial knowledge by financial expensed, interest rate, and credit; the term about credit files and credit rating; financial management; money investment; and anything that occurred in the credit report. 
A person's financial knowledge can affect how they arrange their attitude towards their financial management behavior (Herdjiono \& Damanik, 2016). Financial knowledge affects financial management behavior based on the theory that explained about a person's attitude is based on their intention and purpose based on the information factors, financial knowledge. When an individual has broad knowledge about finance, it will be considered as the factor in recognizing the right output. Amanah et al. (2016) found that financial knowledge has a positive influence on financial management behavior. It is in contrast with the finding in the study of Herdjiono \& Damanik (2016), which stated that financial knowledge does not influence financial management behavior. Thus, the hypothesis is as follows, H3: There is an influence between financial knowledge towards financial management behavior to the millennial generation in Surabaya.

\section{Childhood Consumer Experience}

Childhood consumer experience is the primary determinant of financial behavior, which showed that the involvement of financial practice and consumer in childhood age might have an essential influence on financial practice and behavior in the future (Sabri \& Macdonald, 2010). Childhood consumer experience is an experience in childhood age which is related to finance, for instance, a discussion about finance with their parents (Winata \& Memarista, 2015). As stated by Winata \& Memarista (2015), the parameter to measure the childhood consumer experience is consists of having personal account savings, receiving a personal allowance, and discussing finance.

Childhood consumer experience is the primary decision-maker of financial behavior, which showed that the involvement of financial practice and consumer in childhood age might have essential influences on financial practice and behavior in the future (Sabri \& Macdonald, 2010). The impact of childhood consumer experience towards financial management behavior is based on the theory of planned behavior that explained about a person does several attitudes because they have their intention and purpose with the background of information factors; one of them is the experience. The more early a child has experience in finance, the more they have an excellent effect on financial satisfaction and also the financial management behavior in the future. Falahati et al. (2012), as well as Widyaningrum \& Kurniawati (2018), found that childhood consumer experience has a positive influence on financial management behavior. Meanwhile, the finding is not correlated with the discovery of Sabri \& Macdonald (2010) which stated that childhood consumer experience has a negative influence on financial management behavior. A person with more significant power on consumer experience in childhood age does not tend to 
involve in saving behavior (Sabri \& Macdonald, 2010). Thus, the hypothesis is as follows, H4: There is an influence between childhood consumer experience towards financial management behavior to the millennial generation in Surabaya.

\section{Financial Socialization Agent}

According to Falahati \& Paim (2011), financial socialization is a process of adolescent to gain relevant knowledge, skill, and attitude to the useful function in financial problems. Based on Winata \& Memarista (2015), financial socialization agents are divided into two, the primary agents and the secondary agents. Primary agents are the main agents of socialization in every person's life; meanwhile, the secondary agents are socializing the others. The parameter used to measure primary agents is from father, mother, siblings, religion, and school. On the other hand, the secondary agents are from friends, mass media, magazines, advertisements, internet, and gadget (Winata \& Memarista, 2015).

Primary agents are the main socialization agents in everyone's life (Winata \& Memarista, 2015). The influence of primary agent towards financial management behavior is based on the theory of planned behavior that a person is doing something because they have background factors where parents, siblings, school, are the primary source of the vital learning information. The more knowledge they gain from the primary agents, the better the financial management behavior is. Falahati et al. (2012) mentioned that primary agents have a positive influence on financial management behavior, where the parent's learning session is very influential towards financial management behavior. In contrast, it is different from the finding of Kim \& Chatterjee (2013) that found primary agents has a negative influence on financial management behavior. Most of the respondents who have their parents in monitoring their expense in the childhood age have less worry about their finance and has no full responsibility to manage their financial management. Meanwhile, Cho et al. (2012) stated that primary agents do not influence financial management behavior. Thus, the hypothesis is as follows, H5: There is an influence between primary agents towards financial management behavior to the millennial generation in Surabaya.

Secondary agents are the side of the main socialization agents (Winata \& Memarista, 2015). The influence of secondary agents towards financial management behavior gets its origin from the theory of planned behavior. A person is doing something because of their intention with the background of information factors about the society, mass media, magazine, advertisement, internet, and handphone affect the person's financial management behavior as 
primary agents. The more they gain the learning and information process from the secondary agents, their financial management behavior will be better. Cho et al. (2012) declared that there is a positive influence between secondary agents towards financial management behavior. It is in contrast with the study conducted by Falahati \& Paim (2011), where they found that secondary agents have a negative influence on financial management behavior. The strong impact of secondary management toward financial management behavior and the financial problem showed that they are more influenced by the secondary agents that have risky financial control and involved in the financial problem. Besides, Falahati \& Paim (2011), as the other study, mentioned that the secondary agent does not influence financial management behavior. So, the hypothesis can be concluded as follows, H6: There is an influence between secondary agents towards financial management behavior to the millennial generation in Surabaya. This study then proposed the following conceptual framework:

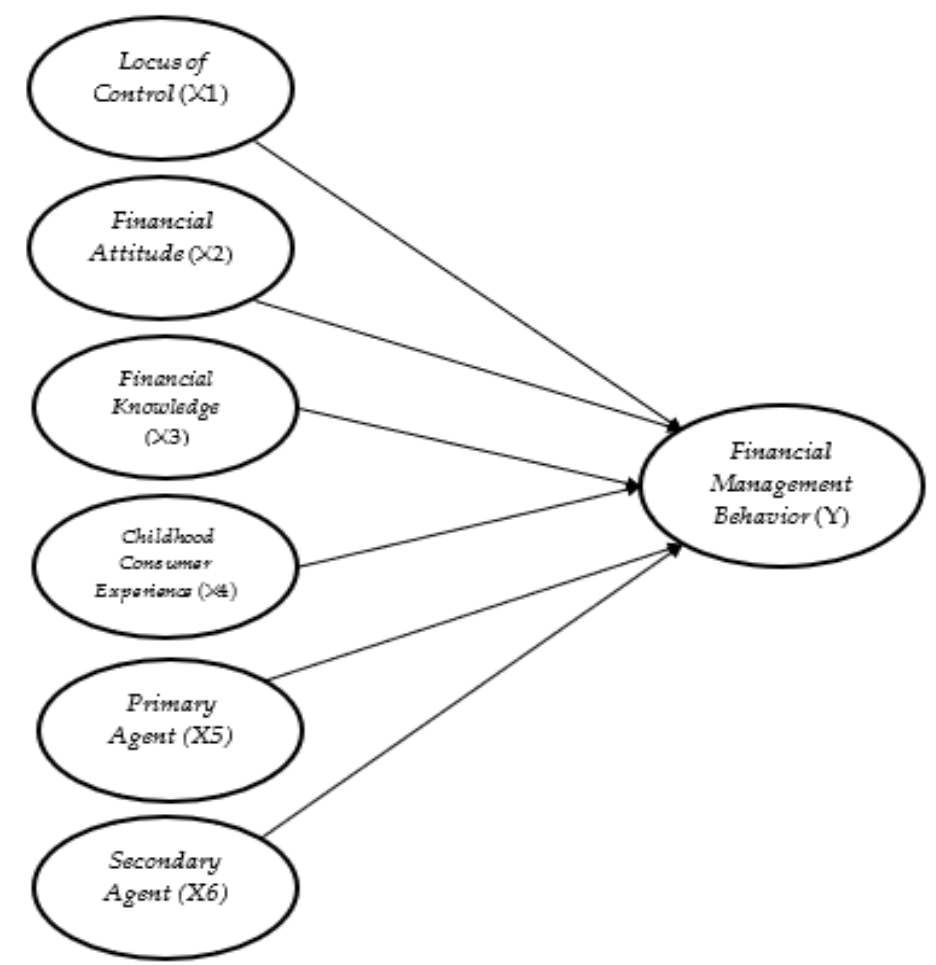

Figure 1. Research Conceptual Framework

\section{METHODOLOGY}

The population of this study is the millennials generation in Surabaya that have criteria minimum 20 years old and a maximum of 34 years old, have ever done online transactions, have income, and domiciled in Surabaya. The technique of sampling data is purposive sampling and snowball sampling. Hair et al. (2014:171) suggested that the sample total is at least five times the item total or the questionnaire spread. There are 36 indicators which consist of statement 
and question that represent the dependent and independent variable. For a reason, the sample size used for this study is at least 180 respondents plus $10 \%$ from the whole samples (Hair et al., 2014:170); in conclusion, the researcher decided to take respondents with the amount of 200.

This study collected primary data and employed the questionnaire as the media of data collection. This study coded the data with 4 points Likert scale. The multiple linear regression becomes the technique of analysis to test the probabilities of influences from more than one independent variable towards the dependent variable.

\section{RESULT}

Table 1. Demographic Respondents Characteristics

\begin{tabular}{|c|c|c|c|c|}
\hline NO & \multicolumn{2}{|r|}{ Category } & $\Sigma$ & $\%$ \\
\hline \multirow{4}{*}{1} & \multirow{4}{*}{ Age } & 20-24 years old & 103 & $56 \%$ \\
\hline & & $25-29$ years old & 51 & $27,7 \%$ \\
\hline & & 30-34 years old & 30 & $16,3 \%$ \\
\hline & & Total & 184 & $100 \%$ \\
\hline \multirow{3}{*}{2} & \multirow{3}{*}{ Gender } & Male & 59 & $32,1 \%$ \\
\hline & & Female & 125 & $67,9 \%$ \\
\hline & & Total & 184 & $100 \%$ \\
\hline \multirow{4}{*}{3} & \multirow{4}{*}{ Income } & $\leq \mathrm{Rp} 1.000 .000$ & 79 & $42,9 \%$ \\
\hline & & > Rp1.000.000 Rp3.000.0000 & 37 & $20,1 \%$ \\
\hline & & > Rp3.000.000 -Rp5.000.0000 & 39 & $21,2 \%$ \\
\hline & & $>$ Rp5.000.0000 & 29 & $15,8 \%$ \\
\hline & & Total & 184 & $100 \%$ \\
\hline
\end{tabular}

Source: processed data by the writer, 2019

The index rate answer can be computed with this formula:

Index Rate $=\{(\% F 1 \times 1)+(\% F 2 \times 2)+\cdots+(\% F n \times n)\} / n \ldots \ldots\left(1^{\text {st }}\right.$ equation $)$

Wherein:

$\mathrm{N}$ : Total score

$\% \mathrm{~F}$ : Respondent frequencies that answer $\mathrm{n}$ score

Based on the formula, the variable except for childhood consumer experience that used Likert scale 1- 4, counted as follows:

Upper limit : $\left(\% \mathrm{~F}^{*} 4\right) / 4=(200 * 4) / 4=200$

Lower limit $:\left(\% \mathrm{~F}^{*} 1\right) / 4=(200 * 1) / 4=50$

Based on the calculation, the index rate with score 50-200 and range 150. To use the three-box method, the 150 scales are divided into three parts to give 
the result 50 of each range to be the index representation, as mentioned in table 2. (Ferdinand, 2006:292):

Table 2. Three Box Method

\begin{tabular}{|c|c|}
\hline Score & Criteria \\
\hline $50,00-100,00$ & Low \\
\hline $100,01-150,00$ & Medium \\
\hline $150,01-200,00$ & High \\
\hline
\end{tabular}

Source: processed data by the writer, 2019

Meanwhile, for the childhood consumer experience variable with the score 1 until 5 have the calculation as follows:

Upper limit : $\left(\% \mathrm{~F}^{* 5}\right) / 5=(184 * 5) / 5=184$

Lower limit : $\left(\% \mathrm{~F}^{*} 1\right) / 5=\left(184^{*} 1\right) / 5=36,8$

From the calculation mentioned, the index score reaches 36,8-184 and range 147,2 . Following the three-box method, the scale of 147,2 is divided into three parts to give the result 4907 of each range to be the index representation as mentioned in table 3 (Ferdinand, 2006:292):

Table 3. Three Box Method

\begin{tabular}{|c|c|}
\hline Score & Criteria \\
\hline $36,80-85,87$ & Low \\
\hline $85,88-134,94$ & Medium \\
\hline $134,94-184,00$ & High \\
\hline
\end{tabular}

Source: processed data by the writer, 2019

Table 4. Respondent's Response Index Range

\begin{tabular}{|l|l|c|c|}
\hline No & \multicolumn{1}{|c|}{ Variable } & IR & Category \\
\hline 1 & Locus of Control & 131,3 & Medium \\
\hline 2 & Financial Attitude & 143,5 & High \\
\hline 3 & Financial Knowledge & 141 & High \\
\hline 4 & Childhood Consumer Experience & 103,3 & Medium \\
\hline 5 & Primary Agent & 136,1 & Medium \\
\hline 6 & Secondary Agent & 124,1 & Medium \\
\hline 7 & Financial Management Behavior & 150,8 & High \\
\hline
\end{tabular}

Source: processed data by the writer, 2019 
Table 5. The Result of the classic assumption test

\begin{tabular}{|c|c|c|c|c|c|c|c|c|}
\hline \multicolumn{2}{|c|}{ Classic assumption test } & LOC & FA & FK & $\mathrm{CCE}$ & PA & SA & NOTES \\
\hline Normality & Kolmogorov Smirnov & \multicolumn{6}{|c|}{$.200^{*}$} & \multirow{2}{*}{ PASSED } \\
\hline \multicolumn{8}{|c|}{ * passed the Normality test if (Sig $>05$ ) } & \\
\hline Multicollinearity & $\mathrm{VIF} /$ tolerance & \begin{tabular}{|c}
$1.272 /$ \\
$.786^{*}$
\end{tabular} & $\begin{array}{c}1.233 / \\
.811^{*}\end{array}$ & \begin{tabular}{|}
$1.202 /$ \\
$.832^{*}$
\end{tabular} & $\begin{array}{l}1.060 / \\
.943^{*}\end{array}$ & \begin{tabular}{|l|}
$1.496 /$ \\
$.669^{*}$
\end{tabular} & \begin{tabular}{|c}
$1.543 /$ \\
$.648^{*}$
\end{tabular} & \multirow[t]{2}{*}{ PASSED } \\
\hline \multicolumn{8}{|c|}{${ }^{*}$ passed the Multicollinearity test if $(\mathrm{VIF}<10$, tolerance $>.1)$} & \\
\hline Heterocedasticity & Spearman Rank & $.873^{*}$ & $.804^{*}$ & $.997^{*}$ & $.909^{*}$ & $.902^{*}$ & $.936^{*}$ & PASSED \\
\hline
\end{tabular}

Table 6. The Result of Multiple Regression Analysis

\begin{tabular}{|c|c|c|c|c|c|c|}
\hline \multicolumn{7}{|c|}{ Coefficients } \\
\hline & & \multicolumn{2}{|c|}{$\begin{array}{l}\text { Unstandardized } \\
\text { Coefficients }\end{array}$} & \multirow{2}{*}{$\begin{array}{c}\text { Standardized } \\
\text { Coefficients } \\
\text { Beta }\end{array}$} & \multirow[b]{2}{*}{$\mathrm{T}$} & \multirow[b]{2}{*}{ Sig. } \\
\hline \multicolumn{2}{|c|}{ Model } & $\mathrm{B}$ & Std. Error & & & \\
\hline \multirow[t]{7}{*}{1} & (Constant) & .707 & .454 & & 1.558 & .121 \\
\hline & Avg_X1 & .080 & .103 & .061 & .776 & .439 \\
\hline & Avg_X2 & .335 & .102 & .252 & 3.275 & .001 \\
\hline & Avg_X3 & .146 & .071 & .155 & 2.048 & .042 \\
\hline & Avg_X4 & -.012 & .063 & -.013 & -.187 & .852 \\
\hline & Avg_X5 & .056 & .099 & .048 & .568 & .570 \\
\hline & Avg_X6 & .170 & .082 & .179 & 2.087 & .038 \\
\hline
\end{tabular}

Source: processed data by the writer, 2019

Table 7. The Result of Correlation Coefficient

\begin{tabular}{|c|c|c|c|c|}
\hline \multicolumn{5}{|c|}{ Model Summary $^{\mathbf{b}}$} \\
\hline Model & $\mathrm{R}$ & $\begin{array}{c}\mathrm{R} \\
\text { Square }\end{array}$ & $\begin{array}{c}\text { Adjusted } \\
\text { R Square }\end{array}$ & $\begin{array}{c}\text { Std. Error of } \\
\text { the Estimate }\end{array}$ \\
\hline 1 & $.390^{\mathrm{a}}$ & .152 & .123 & .57575 \\
\hline
\end{tabular}

Source: processed data by the writer, 2019

Table 6 showed that the coefficient free variable which is locus of control $(X 1)=0,08$, financial attitude $(X 2)=0,335$, financial knowledge $(X 3)=0,146$, childhood consumer experience $(X 4)=-0,012$, primary agent $(X 5)=0,056$, and secondary agent $(X 6)=0,170$ with variable significance range locus of control, childhood consumer experience, and primary agent $>0,05$. In conclusion, the independent variable, financial attitude, financial knowledge, and secondary agent affected the dependent variable of financial management behavior. Adjusted R Square is used in this study because if there is a new additional pattern that may repair the regression model better than estimation, the additional variable will increase the $\mathrm{R}$ Square rate. In table 7 , the adjusted $\mathrm{R}$ 
square is 0,123 . It showed that the independent variable only is only capable of explaining the dependent variable by $12,3 \%$; other variables beyond this research explain the rest of $87,7 \%$.

\section{DISCUSSION}

\section{The Influence of Locus of Control Towards Financial Management Behaviour}

Based on the regression test, the result is the locus of control does not give influence to financial management behavior. It is because of the respondents who practically feel the helplessness in facing their life problems, or some of them face difficulties with many kinds of life matters, e.g., debts, family matters, etc. It is also common that their environment still influenced the problem. This kind of situation is in contrast that people who tend toward their internal locus of control who faces their challenges with their abilities. This finding is relevant to Novianti et al. (2016) and Britt et al. (2011) that there is no influence of locus of control on financial management behavior.

\section{The Influence of Financial Attitude Towards Financial Management Behaviour}

By using multiple linear regression analysis, the result shows that financial attitude influences financial management behavior. Without an excellent financial attitude, it will become a significant matter for the millennials generation in Surabaya to gain their financial benefit in the future. The millennials generation in Surabaya, who has excellent financial attitudes, tends to be wise compared to the millennial generation in the level of bad financial attitude. It is showed by most of them are focused on the question of "buying things that are necessary to impressed people," and they chose score 4, which means they strongly disagree. It can be concluded that millennial generation in Surabaya is preferred to purchase the goods based on their needs instead of their want, and did not have the intention to impress people. This finding means that financial attitude influences financial management behavior, which as supported by the study of Amanah et al. (2016). It stated that an individual has thoughts, judgment, and opinion about making a saving is not essential so that it made them did not do it. If we keep it in mind, the opinion and judgment (attitude) will always continue and will become a habit or behavior that is hard to be changed.

\section{The Influence of Financial Knowledge Towards Financial Management Behaviour}

As mentioned in the multiple linear regression analysis, it stated that financial knowledge influences financial management behavior. This finding is relevant to the theory of planned behavior, which means that an individual's behavior is based on their intention or purpose, which related to some factors. One of them is sound information allowing the increase of financial knowledge. The millennials generation in Surabaya is the generation with adequate financial knowledge and also can control their financial management behavior well. When 
an individual has a rich experience related to finance, it means that they can convert their expertise to make the right decision. This finding is relevant to the previous study by Amanah et al. (2016). It mentioned that the factor in increasing financial knowledge is from education. The more educated an individual, the more substantial their financial knowledge is.

The Influence of Childhood Consumer Experience Towards Financial Management Behavior

The regression analysis showed that childhood consumer experience does not influence financial management behavior. The reason for childhood consumer experience does not change financial management behavior is because the millennial generation in Surabaya receive their personal allowance since childhood age but did not relevant to the financial knowledge management they had. Most of the respondents had received their benefit since the age of 7 years old. It is showed from the statement "receive personal allowance " with a high index rate, which also means that they habitually manage their money since childhood. The millennials generation in Surabaya also have a low rate of childhood consumer experience from the statement "discussing the finance" with the index at 87,6 included in average category and the question "having personal saving account" with low rate index at 63,8 categorized as low which concluded as most of the respondents did not start the saving activity in the childhood age. The reason is because of the different conditions of the research location. This finding is in line with Falahati et al. (2012) that Malaysia is a more literate country rather than Indonesia.

\section{The Influence of Primary Agent Towards Financial Management Behavior}

This study also found that the primary agent does not influence financial management behavior. It means the primary socialization agent, especially the teacher, does not necessarily impact the increase of millennials' management behavior. For a reason, this finding stated that the millennial generation in Surabaya who receives the financial information by the primary agent is not necessarily having good financial management behavior and thus who also have less financial data from the primary agent either. Cho et al. (2012) found that respondents identified their parents as a person who loves to save money when they grow up. The respondents who showed poor financial planning is because they feel depressed in their growing period.

\section{The Influence of Secondary Agent Towards Financial Management Behavior}

As mentioned by the multiple linear regression analysis, the result showed that secondary agent influenced the financial management behavior. The millennial generation in Surabaya has a relevant character as the typical 
millennials in the literature, which closely related to the digital culture. It is showed that most respondents are more depended on gadgets and the internet. They grow with the internet and gadget. For them, the internet has become their basic needs. If we make a connection with the theory mentioned by Maslow, the internet and device have entered into the pyramid of basic necessities along with the clothes, food, and shelter (Ali \& Purwandi, 2017). This finding supported Cho et al. (2012) research that financial information from friends has significantly affected their financial management behavior. Equal age and friends play an essential role in deciding a person's saving behavior.

\section{FURTHER STUDY}

This study obtained a low rate of the adjusted $\mathrm{R} 2$ rate of only $12,3 \%$. Further research should conduct more profound research on financial management behavior. Other variables could provide a better explanation, e.g., financial literacy, parental income, personality, gender, etc. Additional indicators in measuring consumer activity in childhood age also could present a better result. The exciting part of the finding is the secondary agent influenced financial management behavior. Secondary influence, for instance, peers, or the gadget, could also contribute to the millennials' financial management behavior.

\section{REFERENCES}

Ajzen, I. (1991). The Theory of Planned Behavior. ORGANIZATIONAL BEHAVIOR AND HUMAN DECISION PROCESSES, 50(2), 179-211.

Ajzen, I. (2005). Attitude, Personality, and Behavior (2nd ed.). New York: Open University Press.

Akben-selcuk, E. (2015). Factors Influencing College Students ' Financial Behaviors in Turkey : Evidence from a National Survey. International Journal of Economics and Finance, 7(6), 87-94. https:/ / doi.org/10.5539/ijef.v7n6p87

Al Kholilah, N., \& Iramani, R. (2013). Studi Financial Management Behavior Pada Masyarakat Surabaya. Journal of Business and Banking, 3(1), 69-80.

Ali, H., \& Purwandi, L. (2017). The Urban Middle-Class Millennials Indonesia: Financial and Online Behaviour.

Amanah, E., Rahadian, D., \& Iradianty, A. (2016). Pengaruh Financial Knowledge, Financial Attitude Dan External Locus of Control Terhadap Personal Financial Management Behavior Pada Mahasiswa S1 Universitas Telkom. E-Proceeding of Management, 3(2), 1228-1235. https://doi.org/ISSN 2355-9357

Britt, S., Cumbie, J., \& Bell, M. (2011). The Influence Of Locus Of Control. College Student Journal, 47(1), 178-185.

Cho, S. H., Kim, J., \& Mauldin, T. (2012). The Effect of Socialization and Information Source on Financial Management Behaviors among Low- and Moderate-Income Adults. Family E Consumer Sciences Research Journal, 40(4), 417-430. https:// doi.org/10.1111/j.1552-3934.2012.02120.x

CNN Indonesia. (2018). Alasan Generasi Millenial Lebih Konsumtif. Retrieved 
November 22, 2018, from https://www.cnnindonesia.com/gayahidup/20180418215055-282-291845/alasan-generasi-milenial-lebihkonsumtif

Dew, J., \& Xiao, J. (2011). The Financial Management Behavior Scale: Development and Validation. Journal of Financial Counseling and Planning, 22(1), 43-60. https://doi.org/10.5829/idosi.mejsr.2012.12.10.79

Falahati, L., \& Paim, L. H. (2011). Toward a framework of determinants of financial management and financial problems among university students. African Journal of Business Management, 5(22), 9600-9606.

Falahati, L., Sabri, M. F., \& Paim, L. H. J. (2012). Assessment a Model of Financial Satisfaction Predictors : Examining the Mediate Effect of Financial Behaviour and Financial Strain. World Applied Sciences Journal, 20(2), 190-197. https://doi.org/10.5829/idosi.wasj.2012.20.02.1832

Ferdinand, A. (2006). Metode Penelitian Manajemen: Pedoman Penelitian Skripsi, Tesis, dan Disertai Ilmu Manajemen. Semarang: Universitas Diponegoro.

Hair, J. F., Black, C., Babin, \& Anderson. (2014). Multivariate Data Analysis (7th ed.). Pearson Prentice Hall.

Herdjiono, I., \& Damanik, L. A. (2016). Pengaruh Financial Attitude, Financial Knowledge, Parental Income Terhadap Financial Management Behavior. Jurnal Manajemen Teori Dan Terapan, 9(3), 226-241.

Humaira, I., \& Sagoro, E. M. (2018). Pengaruh Pengetahuan Keuangan, Sikap Keuangan, dan Kepribadian Terhadap Perilaku Manajemen Keuangan Pada Pelaku UMKM Sentra Kerajinan Batik Kabupaten Bantul. Jurnal Nominal, $\operatorname{VII}(1)$.

Ida, \& Dwinta, C. Y. (2010). Pengaruh Locus of Control, Financial Knowledge, Income Terhadap Financial Management Behavior. Jurnal Bisnis Dan Akuntansi, 12(3), 131-144.

Jamal, A. A. A., Ramlan, W. K., Karim, M. A., Mohidin, R., \& Osman, Z. (2015). The Effects of Social Influence and Financial Literacy on Savings Behavior : A Study on Students of Higher Learning Institutions in Kota Kinabalu, Sabah. International Journal of Business and Social Science, 6(11), 110-119.

Jorgensen, B. L., Rappleyea, D. L., Schweichler, J. T., Fang, X., \& Moran, M. E. (2016). The Financial Behavior of Emerging Adults: A Family Financial Socialization Approach. Journal of Family and Economic Issues, 38(1), 57-69. https://doi.org/10.1007/s10834-015-9481-0

Kholilah, N. Al, \& Iramani, R. (2013). Studi Financial Management Behavior Pada Masyarakat Surabaya. Journal of Business and Banking, 3(1), 69-80.

Kim, J., \& Chatterjee, S. (2013). Childhood Financial Socialization and Young Adults ' Financial Management. Journal of Financial Counseling and Planning, 24(1), 61-79. https:/ / doi.org/10.2307/2061715

Marsh, B. A. (2006). Examining the Personal Finance attitudes, behaviors, and knowledge levels of first-year and senior students at Baptist Universities in the State of Texas, (October).

Noble, S. M., \& Schewe, C. D. (2003). Cohort segmentation: An exploration of its validity. Journal of Business Research, 56(12), 979-987. 
https://doi.org/10.1016/S0148-2963(02)00268-0

Novianti, S., Tanjung, A. R., \& Darlis, E. (2016). Pengaruh Locus of Control, Financial Knowledge, Income Terhadap Financial Management Behavior. Jurnal Ekonomi, 24(September), 141-152.

Rizkiawati, N. L., \& Asandimitra, N. (2018). Pengaruh demografi, financial knowledge, financial attitude, locus of control dan financial self-efficacy terhadap financial management behavior masyarakat surabaya. Jurnal Ilmu Manajemen, 6(2010).

Robbins, S. P., \& Timothy, A. J. (2008). Perilaku Organisasi (12th ed.). Jakarta: Salemba Empat.

Rotter, J. B. (1966). Generalized Expectancies for Internal Versus External Control Of Reinforcement. Psychological Monographs: General and Applied, 80(1). https:/ / doi.org/10.1037/h0092976

Sabri, M. F., \& Macdonald, M. (2010). Savings Behavior and Financial Problems Among College Students: The Role of Financial Literacy in Malaysia, 6(3), 103-110.

Sabri, M. F., Macdonald, M., Hira, T. K., \& Masud, J. (2010). Childhood Consumer Experience and the Financial Literacy of College Students in Malaysia. Family $\mathcal{E}$ Consumer Sciences Research Journal, 38(4), 455-467. https://doi.org/10.1111/j.1552-3934.2010.00038.x

Sugianto, F. (2018). Indonesian Online Shopping Behavior.pdf. Retrieved from https://snapcart.global/indonesian-e-commerce-shopping-behavior/

Sundarasen, S. D. D., Rahman, M. S., \& Danaraj, J. (2016). Impact of Financial Literacy, Financial Socialization Agents, and Parental Norms on Money Management. Journal of Business Studies Quarterly, 8(April 2017).

Thi, N., Mien, N., \& Thao, T. P. (2015). Factors Affecting Personal Financial Management Behaviors: Evidence from Vietnam. Proceedings of the Second Asia-Pacific Conference on Global Business, Economics, Finance, and Social Sciences, 10-12.

Van Horne, J. C., \& Wachowicz, J. M. (2006). Fundamentals of Financial management. Professional Housing Management Practices in Hong Kong (13th ed.). England: Pearson Education Limited.

Widyaningrum, S., \& Kurniawati, S. L. (2018). Pengaruh Sikap Keuangan, Pengetahuan Keuangan Dan Pengalaman Keuangan Terhadap Perilaku Pengelolaan Keuangan Keluarga Di Sidoarjo. STIE Perbanas, (45), 39.

Winata, J., \& Memarista, G. (2015). Faktor-Faktor yang Mempengaruhi Financial Satisfaction pada Mahasiswa Universitas Kristen Petra. Finesta, 3(2), 1-6.

Yap, R., Komalasari, F., \& Hadiansah, I. (2016). The Effect of Financial Literacy and Attitude on Financial Management Behavior and Satisfaction. International Journal of Administrative Science E Organization, 23(3).

Zakaria, R. H., Ismawati, N., Jaafar, M., Marican, S., Economics, F., \& Lumpur, K. (2012). Financial Behavior and Financial Position: A Structural Equation Modelling Approach. Middle-East Journal of Scientific Research, 12(10), 13961402. https://doi.org/10.5829/idosi.mejsr.2012.12.10.79 